\title{
Teknik Pengelolaan Stress Model Inkubasi Kelompok Budidaya Ikan Program Antisipasi Pandemi Berkelanjutan
}

\author{
A Sofwan F Alqap ${ }^{1}$, Agus Suandi ${ }^{2}$, Hendri Hestiawan ${ }^{3}$, Rozan Ismatul Maula $^{4}$, Nuruliman Supardi ${ }^{5}$, \\ Rachmat Fazabik \\ ${ }^{122) 3556)}$ Teknik Mesin Universitas Bengkulu, Bengkulu, Indonesia \\ ${ }^{4)}$ Universitas Mercu Buana, Yogyakarta, Indonesia
}

Corresponding Author: A Sofwan F Alqap, mao.moe@gmail.com

\begin{abstract}
Abstrak: Pandemi Covid-19 memaksa setiap orang dirumahkan dari pekerjaan. Kapan keadaan akan pulih, tidak tahu. Akankah kembali kepada pekerjaan yang sejenis, belum tentu. Keadaan stress yang berkelanjutan menjadi ancaman kepada banyak orang. Mereka memerlukan pertolongan, baik untuk mengelola dampak terkait emosi, juga membangun apa yang serba baru, baik terkait rasa, identifikasi siapa diri, bisa menjadi apa, dan mencoba aktif di dalamnya. Saran psikologi diberikan untuk pengembangan model mengelola stress, menyenangkan, membangun harapan, menjaga saling kontak sosial, saling memperkuat, berlangsung secara berkelanjutan dan diharapkan berdampak menciptakan efek ganda bagi pengembangan segmen masyarakat sejahtera baru kemudian. Model ini menjadi inkubator bagi kegiatan baru. Kelompok sasaran adalah para buruh harian lepas di bidang bangunan. Tujuan kegiatan adalah memperkenalkan kepada peserta jenis kegiatan baru untuk mengisi waktu luang mereka. Hasil yang diharapkan dari kegiatan adalah para peserta melakukan kegiatan baru yang ditawarkan di tengah keluarga, lalu saling berinteraksi sesama peserta melalui media sosial untuk berbagi pengetahuan dalam memecahkan kendala yang dihadapi. Hasil yang diperoleh menunjukkan mereka aktif berinteraksi di media sosial mendiskusikan kendala atau berbagi berita kemajuan percobaan mereka dengan kegiatan baru. Ini memberi petunjuk ada hasil yang positif tentang model pengelolaan stress bagi para buruh lepas harian dari kegiatan baru yang ditawarkan kepada mereka.
\end{abstract}

Kata Kunci: Pengelolaan stres; pekerja dirumahkan; buruh harian lepas; inkubator; kontak sosial online

Abstract: The Covid-19 pandemic forced everyone laid off. When the situation recover, no one knows. Will he/she returns to similar work, does not sure. Continuing stress threats to many people. They need helps, to manage the emotional related impact, to build what is new about sense, whom he/she might be, to carry on a recent part, and try to be active in it. Psychological advice was given to develop a sustaining model for managing stress, enjoying, making hope, maintaining social contact, sharing each other, on being an incubator in effect to emerge a prosperous activity next. The target group is the low level of open workers in the construction sector who have lost their jobs. The purpose of the activity is to introduce participants to an alternative work to fill their idle time. The expected result of the activity is that the participants carry out the new work amongst their family and interact with each other through social media to share knowledge in solving the obstacles they face. The results obtained showed that they actively interacted on social media discussing obstacles or sharing news of the progress of their experiments with the new work. This indicates that there are positive results regarding the stress management model for the low income of workers by the new work offered to them.

Keywords: stress management; loss of job; low level of open workers; incubator; online social contact

Submitted: 02-04-2021, Revised: 08-08-2021, Accepted: 01.10.2021 


\section{Pendahuluan}

"Dirumahkan!" kenyataan yang banyak orang stress dibuatnya. Tapi pandemi Covid-19 menghendaki keadaan ini secara massal (Astuti, 2021) Artinya banyak orang yang terancam oleh keadaan yang membuat stress. "Dampak terkait emosi oleh kehilangan pekerjaan dapat melampaui stress akibat persoalan keuangan, karena mungkin lebih berpengaruh kepada identitas atau rasa diri. Terlebih jika pekerjaan itu yang kita sukai, atau berupa karir yang sudah dibangun bertahun-tahun (Maitlis, 2020).

Meskipun stres karena dirumahkan bisa terasa sangat berat, ada banyak hal yang dapat dilakukan untuk mengendalikan situasi, menjaga semangat, dan menemukan tujuan baru. Kehilangan pekerjaan adalah salah satu pengalaman hidup yang paling menegangkan. Selain penderitaan finansial yang dapat ditimbulkan, stres karena kehilangan pekerjaan juga dapat sangat memengaruhi suasana hati, hubungan, serta kesehatan mental dan emosional secara keseluruhan.

Pekerjaan seringkali lebih dari sekedar cara orang mencari nafkah. Mereka memengaruhi cara kita memandang diri sendiri, serta cara orang lain melihat kita. Sekalipun orang tidak menyukai pekerjaan pada awalnya, pekerjaan itu kemungkinan besar memberinya saluran sosial dan memberi struktur, tujuan, dan makna pada hidupnya. Kemudian tiba-tiba menemukan diri dikeluarkan dari pekerjaan, hal itu dapat membuat diri merasa sakit hati, marah, atau tertekan. Orang mungkin mempersoalkan identitas alasan, berduka atas semua yang hilang, atau merasa cemas tentang masa depan. Bergantung pada keadaan pengangguran, mungkin merasa dikhianati oleh majikan, tidak berdaya atas arah hidup berikutnya, atau menyalahkan diri atas kekurangan atau kesalahan yang dirasakan. Stres dan kekhawatiran bisa membuat orang kewalahan. Tapi betapapun suramnya keadaan, harapan akan selalu ada. Jika waktu dan teknik mengatasi masalah diberikan dengan tepat, setiap orang dapat menerima keadaan yang kurang beruntung, dapat meredakan stres dan kecemasan, dan tegar untuk lanjut kepada kehidupan kerja berikut. (Smith, et al., 2020).

Kini hilangnya pekerjaan disebabkan oleh pandemi Covid-19 yang melanda dunia. Kapan keadaan akan pulih tidak bisa dipastikan sedangkan yang lain akan muncul dalam bentuk yang berbeda. Dirumahkan oleh Covid-19 membuat banyak orang berhenti atau diberhentikan dari pekerjaan. Sayangnya banyak orang yang dirumahkan tidak dapat kembali kepada pekerjaan yang sejenis. Mereka memerlukan pertolongan tidak hanya untuk mengelola dampak terkait emosi, tetapi juga membangun rasa yang baru tentang siapa dirinya, siapa dia bisa menjadi apa, dan berusaha mencoba aktif dalam peran dan identitas baru (Maitlis, 2020).

Stres dapat didefinisikan sebagai tingkat di mana diri merasa kewalahan atau tidak mampu mengatasinya sebagai akibat dari tekanan yang tidak terkendali (Mental Health, ND) Stres memengaruhi semua orang. Gejala stres mungkin akan terlihat saat mendisiplinkan anak, saat sibuk di tempat kerja, saat mengelola keuangan, atau saat menghadapi hubungan yang menantang. Stres ada dimana-mana. Sedikit stres tidak masalah, bahkan sebagian stres sebenarnya bermanfaat. Tetapi terlalu banyak stres dapat membuat lelah, penat dan sakit, baik secara mental maupun fisik.

Stres adalah reaksi tubuh terhadap situasi berbahaya - baik yang nyata atau hanya persepsi. Saat diri merasa terancam, reaksi kimia terjadi di tubuh untuk mencegah kalau-kalau terjadi cedera. Selama respons stres, detak jantung meningkat, pernapasan menjadi lebih cepat, otot menegang, dan tekanan darah meningkat. Ini persiapan untuk bertindak. Begitulah cara sistem tubuh melindungi diri. 
Sedikit stres sesekali bukanlah sesuatu yang perlu dikhawatirkan. Namun, stres kronis yang terus-menerus dapat menyebabkan atau memperburuk banyak masalah kesehatan yang serius. Di antaranya: Masalah kesehatan mental, seperti depresi, kecemasan, dan gangguan kepribadian. Penyakit kardiovaskular, termasuk penyakit jantung, tekanan darah tinggi, irama jantung yang tidak normal, serangan jantung, dan stroke. Obesitas dan gangguan makan lainnya. Masalah menstruasi. Disfungsi seksual, seperti impotensi dan ejakulasi dini pada pria dan hilangnya hasrat seksual baik pada pria maupun wanita. Masalah kulit dan rambut, seperti jerawat, psoriasis, dan eksim, serta rambut rontok permanen. Masalah gastrointestinal, seperti GERD, gastritis, ulcerative colitis, dan iritasi usus besar. Dan lain-lain. Banyak gejala stres bisa menjadi tanda dari masalah kesehatan. Ketika begitu, gejala yang lain akan dikesampingkan oleh dokter (WebMD, nd).

Stres memiliki arti yang berbeda bagi orang yang berbeda. Apa yang menyebabkan stres pada satu orang mungkin menjadi perhatian kecil bagi orang lain. Beberapa orang lebih mampu mengatasi stres daripada yang lain. Dan, tidak semua stres itu buruk. Dalam dosis kecil, stres dapat membantu kita menyelesaikan tugas dan mencegah kita terluka. Misalnya, stres adalah apa yang membuat kita reflek menghindari menabrak mobil. Ini bagus. Tubuh kita dirancang untuk menangani stres dalam dosis kecil. Tetapi, kita tidak diperlengkapi untuk menangani stres jangka panjang dan kronis tanpa akibat buruk.

\section{Apa Gejala Stres?}

Mungkin yang dirasa dari stres adalah masalah emosional - sesuatu yang hidup di dalam kepala. Tetapi stres juga bisa menjadi masalah fisik, terutama saat menghadapi hal-hal yang paling membuat stres dalam hidup. Stres dapat memengaruhi semua aspek kehidupan, termasuk emosi, perilaku, kemampuan berpikir, dan kesehatan fisik. Tidak ada bagian tubuh yang kebal. Gejala bisa tidak jelas dan mungkin sama dengan yang disebabkan oleh kondisi medis. Meski semua orang mengalami stres, tetapi banyak yang tidak tahu cara mengelolanya. Saat penyebab utama stres muncul, penting untuk menanganinya dengan benar agar tidak terluka. Lima peristiwa hidup yang paling menegangkan meliputi: Kematian orang yang dicintai, perceraian, mutasi, penyakit atau cedera berat, dan kehilangan pekerjaan (Uh Hospital, 2015).

Tetapi menurut survey AARP tahun 2014 even yang paling utama menyebabkan stress adalah: kematian pihak yang disayangi, penyakit kronis, tugas merawat orang sakit, kehilangan pekerjaan, dan berganti atau mutasi. Sedangkan sebab-sebab utama terhadap stress adalah: uang, kesehatan, anak atau cucu, sendirian atau kesepian dan depresi, tugas merawat orang sakit (Agnvall, 2014).

\section{Mekanisme Stress Merusak Kesehatan}

Tubuh memiliki sistem pertahanan diri terprogram yang biasa dikenal sebagai respon "lawan-atau-lari". Respon semestinya terjadi saat menghadapi ancaman dan langsung berhenti saat ancaman berlalu. Tetapi, kondisi tubuh bisa terjebak tidak bisa keluar, ketika ini yang terjadi, keadaan bisa menyebabkan masalah kesehatan.

Mekanisme "lawan-atau-lari" dari tubuh adalah sistem penyelamatan hidup alami yang sangat efisien dan efektif. Ini respon saraf simpatik. Tetapi, perilaku kehidupan modern bisa menyebabkannya korsleting. Ketika stres berlangsung terus-menerus, hipotalamus, wilayah kecil di dasar otak, memicu alarm yang tidak berhenti menyala. Ketika ini, sistem mengamuk. Alarm dari hipotalamus memicu serangkaian sinyal yang menyebabkan kelenjar adrenal melepaskan lonjakan hormon, termasuk adrenalin dan kortisol. Adrenalin dan kortisol membantu tubuh bertindak selama respons "lawan-atau-lari". Ketika stres berkepanjangan 
tubuh menjadi kurang reflek untuk kembali ke mode relaksasi, sedangkan tubuh terus terkena kortisol dan hormon stres lainnya. Terjadilah fenomena over dosis asupan adrenalin dan kortisol.

Jumlah adrenalin maupun kortisol yang cukup tidak bersifat buruk, bahkan diperlukan. Adrenalin dperlukan untuk meningkatkan detak jantung, tekanan darah, pasokan energi otot, tingkat pernapasan. Kortisol meningkatkan glukosa dalam aliran darah, meningkatkan penggunaan glukosa di otak, meningkatkan ketersediaan zat yang diperlukan untuk memperbaiki jaringan, mematikan peradangan. Selain itu, kortisol memperlambat fungsi tubuh yang tidak penting sehingga jumlah energi maksimum dapat dialokasikan untuk melindungi diri dari ancaman fisik langsung.

Ketika Anda menghadapi penimbul stres, proses pertumbuhan tubuh, sistem reproduksi, pencernaan, dan kekebalan untuk sementara ditekan. Gelombang dan fokus energi ini berguna jika beruang menghadang, misalnya. Namun jika stres berasal dari penyebab stres yang lebih umum seperti beban kerja yang berat dan tagihan yang menumpuk, respons "lawan atau lari" yang terus menerus bukanlah pertahanan tubuh yang baik. Inilah mengapa manajemen stres itu penting dalam kehidupan.

Jika tubuh menangani stres dengan benar, respons relaksasi akan mengikuti respons "lawan-atau-lari". Ini terjadi karena pelepasan hormon yang melawan. Selama respons relaksasi dari sistem saraf parasimpatis, tubuh bergeser kembali ke keseimbangan. Ini memungkinkan detak jantung dan tekanan darah kembali ke tingkat dasar dan memungkinkan aktivitas seperti pencernaan dan tidur untuk dilanjutkan dengan kecepatan normal. Stres berkepanjangan membuat tubuh terus menerus dalam keadaan siap melakukan tindakan fisik. Tubuh terpapar aliran kortisol tanpa henti, sel menjadi peka terhadap hormon, keadaan ini menyebabkan peradangan yang liar. Peradangan kronis jangka panjang merusak pembuluh darah dan sel otak, menyebabkan resistensi insulin (pendahulu diabetes) dan meningkatkan penyakit sendi yang menyakitkan.

Ketika tubuh tidak punya waktu untuk memulihkan keseimbangan, itu menjadi terlalu banyak bekerja dan sistem kekebalan akan melemah, membuat tubuh rentan terhadap penyakit. Banyak proses penting tubuh terganggu dan risiko masalah kesehatan meningkat (Agnvall, 2014; WebMD, nd; Health Line, 2018)

\section{Keluhan Akibat Stress}

Di antara keluhan yang mungkin terjadi oleh stress adalah: demam pada umumnya, berat badan bertambah, penyakit yang ada sulit sembuh, kesulitan tidur, keluhan jantung, depresi, bisul dan gatal-gatal, sakit perut, nyeri otot di punggung, leher dan bahu.

Demam itu pertanda ada peradangan. Kortisol adalah bagian dari sistem kekebalan tubuh yang berfungsi menyembuhkan peradangan. Tetapi ketika tubuh sudah resisten terhadap kortisol, maka sistem kekebalan tubuh sudah berkurang, maka orang menjadi rentan terhadap demam, karena tidak ada penyembuhan terhadap peradangan.

Selera ngemil atau mengunyah permen mungkin saja pertanda dari gejala stress, karena hormon stress merangsang kecenderungan mengambil makanan mengandung gula, pati dan lemak. Tetapi yang menjadi persoalan adalah ketika stres berlangsung selama 24 jam maka tubuh penderitanya kemudian akan mengalami kerja lambat membakar 104 kalori per 7 jam, dibandingkan orang yang tanpa stress sebelumnya. Keadaan seperti ini akan menambah berat badan 11 pound atau nyaris $5 \mathrm{~kg}$ dalam se tahun, peningkatan insulin, penurunan oksidasi lemak, sehingga lemak di perut meningkat (Agnvall, 2014)

Penelitian pada orang memiliki luka dan ia bekerja merawat orang sakit. Dia memerlukan waktu penyembuhan luka 10 hari lebih lama dibanding orang yang tidak bekerja 
merawat orang sakit. Semakin lama stres berlangsung maka semakin lama respon kekebalan terganggu. Orang yang bekerja merawat yang tidak memiliki jaringan pertemanan atau kekeluargaan yang kuat akan lebih lambat lagi untuk sembuh.

Orang yang terjaga dari tidur terkadang sulit untuk kembali tidur. Ini mungkin disebabkan oleh stress. Terjaga dari tidur dapat diakibatkan oleh aktivitas kortisol. Kemudian keadaan stress menggiring otak merespon dengan mengingat tentang masalah penimbul stres. Siklus dari stress menyebabkan disfungsi tidur, dan keadaan disfungsi tidur menjadi stress tersendiri. Siklus ini membuat orang sulit mengatasi masalah gangguan tidur.

Sampel darah orang terkena gangguan stres mengandung kelebihan kadar sel darah putih. Sementara kortisol berfungsi mengubah tekstur sel darah putih yang dapat menempel ke dinding pembuluh darah. Akibatnya akan menghasilkan pengerasan pada arteri dan adanya plak sebagai penanda utama penyakit jantung.

Depresi berat mengakibatkan peningkatan kadar kortisol secara permanen, kemudian mengubah hipokampus dan merusak sel-sel otak secara permanen. Stress yang berkepanjangan membuat sistem transmisi saraf dalam otak menjadi tidak seimbang yang berdampak pada suasana hati, nafsu makan, tidur dan libido.

Sistem kekebalan tubuh yang tidak berfungsi dengan baik oleh adanya stress berkepanjangan, dapat mengakibatkan bakteri $\mathrm{H}$ pylori dalam usus berkembang tanpa terkendali, iritasi usus besar, mulas, gangguan pencernaan, bahkan mungkin keluar sebagai bisul.

Pegal di leher, bahu dan punggung bagi pekerja di depan komputer tidaklah mengherankan. Robekan cakram, stenosis tulang belakang dan skoliosis mungkin akan sembuh ketika siklus mineralisasi-demineralisasi masih berlangsung dengan normal. Tetapi ketika ini terjadi kemudian diterima sebagai rasa stres maka keadaan ini dapat meningkatkan keparahan dan lama waktu pemulihan (Agnvall, 2014).

\section{Teknik Mengelola Stress}

Untuk mengelola stres sehingga stres itu menjadi hal yang normal, wajar dan positif maka penawar atau penangkal untuk stress perlu dikenali. Secara ringkas ada empat jenis. Yaitu: (a) berpikir positif terhadap sumber stress, (b) menjaga hubungan sosial tetap berlangsung, (c) menjaga tetap aktif, berlatih, berolahraga, dan berkegiatan positif lainnya, dan (d) mengambil nafas sedalam-dalamnya, yoga dan berdoa-bersembahyang atau kegiatan meditasi lainnya (Andrade dan Radhakrishnan, 2009; Schlitz, 2005; Doufesh dkk, 2014; Duckro dan Magaletta, 1994; Masters dan Spielmans, 2007; Alwasiti dkk, 2010).

Berikut ini petunjuk praktis teknik mengelola stress dari para psikolog.

Kegiatan fisik secara aktual dapat mengatur ulang otak, membantu meredakan stress.

Kontak sosial secara aktual. Mereka yang bergabung dengan voluntir sosial mengalami stress yang lebih sedikit dibanding yang tidak ikut.

Berkebun. Meluangkan waktu 30 menit berkebun di alam terbuka meredakan stress yang ditunjukkan pada perbaikan level kortisol maupun mood.

Meditasi dengan pikiran, konsentrasi atau fokus yang hadir. 25 menit meditasi yang bermakna selama 3 hari berturut turut cukup membuat orang meredakan stress yang diderita.

Beberapa perilaku, kebiasaan dan keberanian yang disarankan.

Membatasi diri pada pekerjaan yang sesuai kemampuan dan pada jadwal untuk diri sendiri. Membuat jarak atau batasan, agar orang tidak mengganggu kita kapan saja, ini diperlukan. Sisakan waktu untuk sendiri dan keluarga. Karena itu diperlukan keberanian untuk berkata "tidak". Termasuk mengatur ada waktu tanpa email. Karena email atau medsos dapat mengganggu waktu 37 kali per jam. Jadwal yang harus dikedepankan adalah waktu 
untuk keluarga, bersama teman, berolahraga, berlibur, voluntir dan hobbi. Ini semua perlu dinyatakan di kalender pertama kali sebelum mengagendakan yang lain. Terkait dengan rumah, tentukan area bebas telepon. Siapkan rumah sebagai tempat untuk bercakap, membaca dan relaks. Matikan TV ketika jadwal menonton selesai. Hindari waktu di layar sebelum tidur. Karena dapat menimbulkan masalah tidur. Mengakses berita umum di media dibatasi tidak lebih dari 30 menit per hari. Menjauhi selular saat jadwalnya off darinya (Agnvall, 2014)

Untuk menghindari potensi berkembangnya penyakit terkait stres perilaku berikut ini disarankan.

Melepaskan ketegangan fisik dengan berhenti duduk saat bekerja, menggantinya dengan berdiri; Membiasakan kerja fisik ringan seperti menaiki tangga, atau berjalan kaki selama lima menit.

Mendengarkan lantunan merdu melalui headphone di tempat kerja, saat melaju, atau saat istirahat makan siang.

Membicarakan tentang masalah yang membuat stres. Bukan bermakna curhat yang merusak. Maksudnya bicarakan apa yang membuat stres, hadapi, tidak menghindari. Ini akan membantu melepaskan kecemasan yang terkait dengannya dan dapat mengarah pada pemulihan.

Menyedikitkan pemicu stres. Jika pekerjaan dan kewajiban hidup membuat sangat sibuk yang mengembangkan penyakit yang berhubungan dengan stres, gagasan untuk menambah acara lain tidak disarankan. Meskipun mungkin cara untuk mengurangi stres.

Hidup tidak mungkin sepenuhnya bebas stres, jadi pastikan untuk mengendalikan stres dan luangkan waktu yang diperlukan untuk tetap sehat, produktif, dan bahagia (Health Line, 2018).

Menerima keadaan. Orang mengira bahwa dengan mengabaikan stress, menghindari atau dengan menyibukkan diri kepada kegiatan yang lain adalah cara mengatasi keadaan stress. Cara seperti ini tidak menyelesaikan. Keadaan yang sama akan tetap datang tetapi kita sudah tidak memiliki kepekaan untuk merasakannya lagi. Yang lebih menolong adalah beri diri kita kesempatan untuk merasakan diri dalam suasana yang baru, sambil mengenali emosiemosi yang terjadi di bawah situasi tersebut.

Membangun rasa dalam suasana yang baru. Di tempat yang kita bisa atur secara emosional, kita dapat mengenali apa yang sudah terjadi, mengapa dan apa maknanya bagi kita. Psikolog menyebut suasana ini dengan sense-making, mengembangkan rasa, atau mungkin semakna dengan cipta rasa. Proses ini dapat memberi kita sense of control terhadap situasi, khususnya tentang apa yang telah menimpa kita dalam kontek berupa krisis yang lebih berat lagi. Cara ini dapat membangun kepribadian yang berpikir positif terhadap masa depan. Sedangkan cara yang membuat orang terbenam di mana dia berada, yakni ketika kita fokus dengan kesalahan kita dan apa yang telah berjalan secara salah, ini dapat menjelmakan diri yang kurang kenal akan dirinya dan kesulitan untuk melihat peluang ke luar sana.

Mencoba yang baru dan berpadu. Mengembangkan rasa lebih dari sekedar cara berpikir. Sense-making seperti melemparkan pertanyaan-pertanyaan kepada diri sendiri berupa: Apa yang bisa membawa saya kepada kegiatan yang membantu di masa depan? Bagian mana dari diri saya yang tidak dapat dipakai? Bagian mana dari diri saya yang ingin dikembangkan? Seberapa banyak saya bisa menyukai kegiatan itu? Bagaimana harus berjalan baik agar selaras dengan keperluan dan minat yang saya punya? Apa yang harus berbeda pada diri saya pada kegiatan nanti? Jika kita terbiasa mengembangkan rasa ini, kita tidak perlu menunggu krisis untuk mengubah kegiatan, karir dan gaya hidup.

Karir baru seringkali ditemukan dari mencoba hal baru yang sepele. Dari hanya membantu teman, mengembangkan hobby yang lama, menghadiri ceramah, atau menerima 
peran sementara. Ketika hal baru ini terus berlangsung, ini akan menjadi katalis bagi kita untuk menemukan dunia baru. Di samping itu, kita dibantu mengenali diri yang telah diperkaya, diperkuat, ditempa atau dikembangkan melalui pengalaman yang sulit (Maitlis, 2020; Smith dkk, 2020)

Tidak ada yang tidak bisa untuk meluangkan waktu 5 menit, kalau tidak bisa sampai 10 menit, untuk berkegiatan fisik sekedar gerak badan seperti bersembahyang atau senam otak. 30 sampai 60 detik sudah sangat membantu. Tarik napas sedalam-dalamnya sambil berpikir: saya hadir di sini, begini saya apa adanya, ini penerimaan saya. Luangkan waktu untuk merasa nyaman, setidaknya 30 detik. Pikirkan tentang apa yang bisa disyukuri. Mengetuk membunyikan irama sambil bernyanyi atau bahkan menangis (UH Hospitals, 2015).

\section{Metodologi}

(Batubara dkk, 2021) mengambil tema kegiatan budidaya ikan dalam ember (budikdamber) sebagai materi penyuluhan ketahanan pangan di masa sulit akibat larangan beraktivitas di luar rumah akibat Covid 19 tanpa memfasilitasi peserta untuk melakukan kegiatan setelahnya. Di sini setiap peserta sosialisasi budikdamber melakukan praktek budidaya ikan dalam ember dan aktif melakukan komunikasi melalui media sosial untuk mengatasi setiap kendala yang dihadapi dalam melakukan budidaya. Peserta adalah para buruh lepas harian yang bekerja di sektor bangunan.

Buruh lepas harian menghadapi beberapa kendala keterbatasan. Yaitu keterbatasanketerbatasan: sumber daya baik berupa lahan atau ruang, modal maupun pengetahuan, dan keterampilan terkait kegiatan baru.

Agar kegiatan baru ini adalah proses yang keberlanjutan maka model pendekatan disusun sebagaimana ditunjukkan pada Gambar 1.

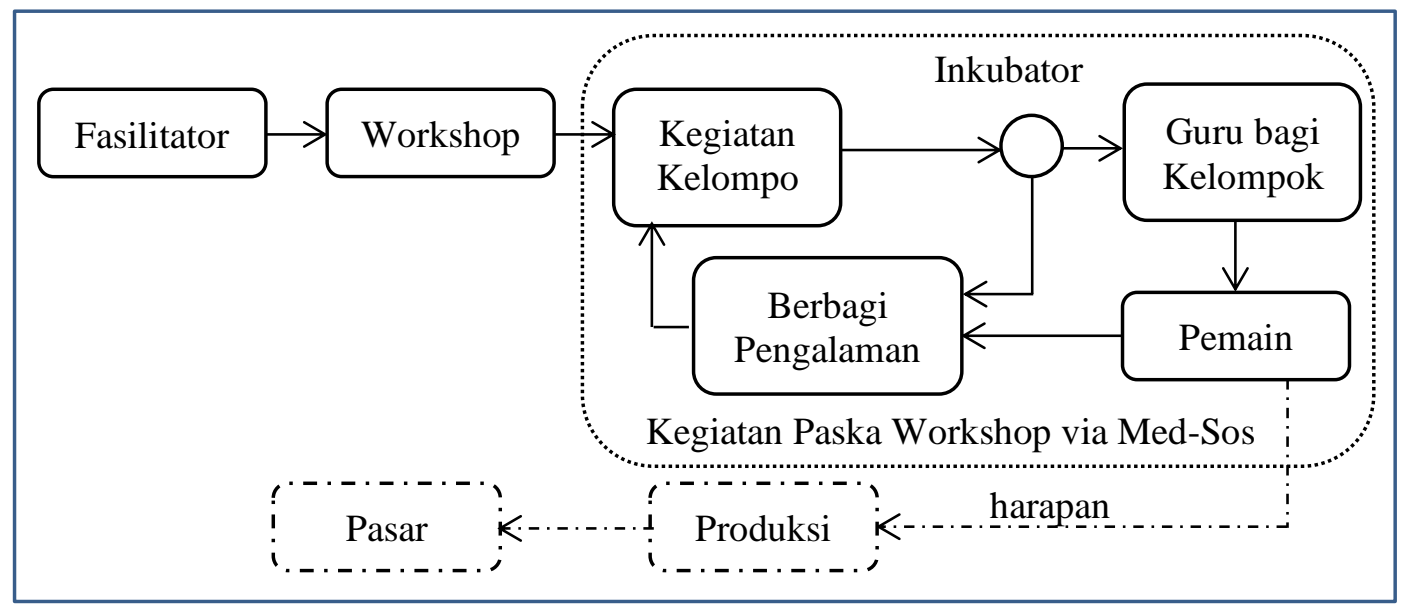

Gambar 1. Model pendekatan inkubasi dan harapan kegiatan

Fasilitator adalah tim pelaksana pengabdian yang menyediakan fasilitas benih ikan, ember, pakan, dan material yang diperlukan untuk memulai budidaya ikan dalam ember. Peserta diperkenalkan kepada kegiatan baru dalam kelompok. Kelompok berkegiatan ini adalah model inkubator, di dalamnya para peserta berinteraksi untuk mengembangkan keterampilan melaksanakan kegiatan dan berbagi pengalaman. Siklus bertukar informasi dan praktek diharapkan memunculkan guru bagi kelompok. Guru yang dimaksud adalah peserta 
yang muncul sebagai pemain karena unggul dalam pengetahuan dan praktek, sehingga dapat menularkan pengalaman dan membimbing rekan-rekan yang lain.

Harapan dari kegiatan inkubator ada dua jenis harapan: harapan jangka pendek dan harapan jangka panjang. Harapan jangka pendek munculnya peserta yang menjadi guru dan (calon/ potensial) pemain. Pemain yang dimaksud di sini adalah peserta yang muncul menjadi praktisi potensial dalam kegiatan baru untuk menghasilkan produk yang tetap atau mengembangkan produk sehingga memenuhi kegiatan yang disebut produksi. Harapan jangka panjang adalah akan munculnya kegiatan produksi dan pasar dari hasil kegiatan produksi. Produksi adalah kegiatan yang mengubah sumber daya menjadi barang komoditi secara tetap dan terus menerus, atau supply, sehingga bernilaikan ekonomi. Kegiatan bernilai ekonomi adalah kegiatan yang berkemampuan memenuhi permintaan pasar, atau demand, secara konsisten dan terus menerus.

\section{Hasil dan Pembahasan}

Kegiatan baru yang diberikan kepada peserta adalah budidaya ikan dalam ember, yaitu pola kegiatan yang diperkenalkan Nursandi (Nursandi, 2018) untuk membudidayakan ikan sekaligus tanaman sayur dalam media yang terbatas.

Ikan adalah obyek yang menarik. Bermain dengan ikan memberi efek kesenangan. Baik anak maupun orang dewasa banyak yang mengambil ikan sebagai obyek rekreasi. Budidaya ikan mudah dilakukan. Dagingnya kaya nutrisi, baik bagi kesehatan, mengandung vitamin $\mathrm{E}$ dan zat anti oksidan yang berguna untuk memulihkan kesehatan dan membantu menghadapi stress.

Manajemen budidaya ikan tidak memerlukan waktu khusus, sehingga dapat dilakukan di sela-sela waktu kegiatan. Seperti dengan mengatur jadwal pemberian pakan sesuai dengan jadwal pekerjaan atau jadwal kantor. Budidaya ikan dapat dilakukan dengan berbagi tugas dengan keluarga dan anak-anak.

Budidaya ikan dalam ember atau dalam terpal tidak memerlukan ruang yang lebar, atau volume yang besar. Dengan biaya yang tidak terlalu besar, atau sebagian tanpa biaya, semua keperluan dapat diadakan. Budidaya ikan adalah kegiatan yang dapat berkelanjutan. Kapan mau, kegiatan bisa dimulai.

\section{A. Hasil}

13 peserta dari kalangan buruh harian lepas mengikuti workshop. Masing-masing mendapat bibit ikan gabus berukuran $2 \mathrm{~cm}$ sebanyak 30 ekor, sebuah ember plastik kapasitas 80 liter lengkap dengan tutup, $3 \mathrm{~kg}$ pakan ikan, $450 \mathrm{~cm}$ kawat diameter 1,5 $\mathrm{mm}$ untuk dudukan 11 gelas pelastik, bibit kangkung, arang sebagai alas bagi media kangkung. Berikut ini adalah materi yang dirangkum dari hasil interaksi para peserta di media sosial dalam rangka memulai praktek budidaya ikan. 13 peserta, yakni $100 \%$, seluruhnya berinteraksi dalam media sosial.

Di antara peserta membagikan pengetahuan bahwa ember sebelum dipakai perlu dicuci, digosok dengan daun pepaya. Sesudah itu air diisikan ke dalam ember hingga tinggi $20 \mathrm{~cm}$ di bawah bibir ember. Daun pepaya ditambahkan ke dalam air. Bibit ikan dalam kantong pelastik tidak langsung dikeluarkan, melainkan pelastiknya ditenggelamkan ke dalam air dalam keadaan talinya dibuka, agar suhu air di kantong pelastik sama dengan suhu air di ember, agar bibit ikan tidak mengalami keterkejutan dengan suhu yang berbeda. Ember ditempatkan di lokasi yang melindungi dari kejatuhan air hujan. Kalau tidak, air hujan akan menambah volume air dan merubah $\mathrm{pH}$ air. 
Penyesuaian suhu air dalam pelastik dengan suhu air dalam ember sekitar 5 jam. Saat ikan dikeluarkan dari dalam pelastik ke dalam ember, pakan ikan ditaburkan sekira se ujung sendok teh untuk satu ekor bibit ikan. Jadwal pemberian pakan ikan 3 kali per hari, pemilihan waktu disesuaikan dengan jam kegiatan rutin masing-masing peserta di luar rumah. Kadar pakan yang diberikan disesuaikan dengan besar pertambahan badan bibit ikan. Bibit kangkung disemaikan di atas kertas tissu yang lembab. Bibit kangkung ditabur di atas kertas.

\section{B. Pembahasan}

Ikan gabus dipilih untuk dibudidayakan karena baik dikonsumsi bagi pasien paska bedah atau bagi perbaikan mutu kembang anak balita, begitu yang dipercaya oleh Masyarakat Bengkulu. Persepsi yang ada pada masyarakat akan menjadi potensi pasar yang baik.

Buruh harian lepas di bidang bangunan tidak begitu terdampak oleh protokoler kesehatan terhadap pandemi Covid-19. Karena kegiatan mereka tidak berinteraksi dengan banyak orang. Hanya saja pandemi Covid-19 menimbulkan dampak resesi ekonomi, sehingga kegiatan pembangunan di beberapa sektor menjadi berhenti. Karena itu banyak dari buruh lepas harian mengalami kekosongan pekerjaan akibat masa pandemi Covid-19. Kekosongan hari-hari mereka perlu diisi dengan bekal pengetahuan bagaimana mereka dapat memiliki keterampilan baru yang baik untuk menjaga vitalitas dan keceriaan mereka se hari-hari.

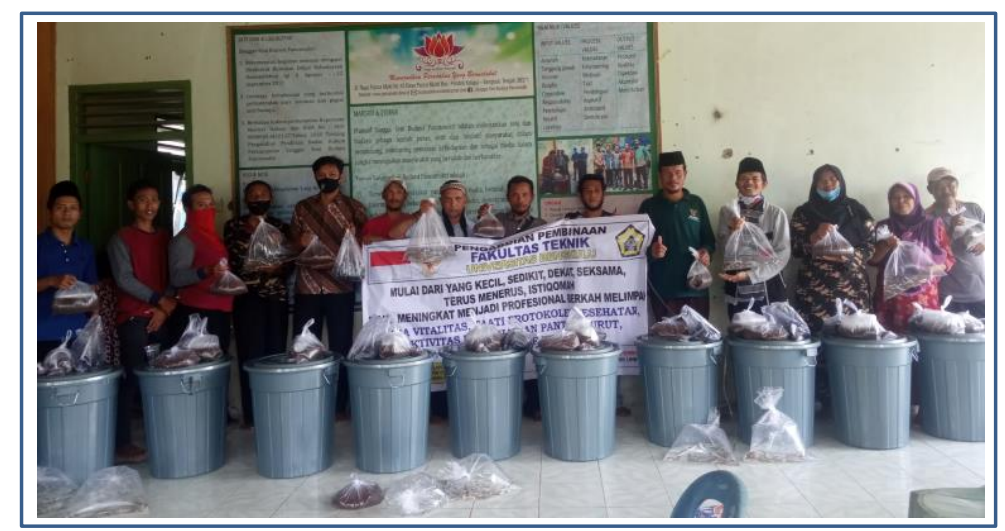

Gambar 2. Workshop dan Peserta Workshop

Item yang muncul dalam interaksi media sosial para peserta dapat dirinci dalam tabel berikut.

Tabel 1. Tingkat interaksi antar peserta menurut tema yang dibincangkan dalam masa 16 hari

\begin{tabular}{|c|c|c|c|c|c|}
\hline Item Terkait & Persiapan & Pakan & Penyakit & Hilang/Mati & Lain \\
\hline Muncul (hari) & 1 & 7 & 4 & 3 & 1 \\
\hline Intensitas (\%) & 6,25 & 43,75 & 25,00 & 18,75 & 6,25 \\
\hline
\end{tabular}

Pengembangan pengetahuan membudidayakan ikan dalam ember dilakukan melalui tukar informasi di media sosial. Tabel di atas dibuat berdasarkan tema perbincangan dalam masa 16 hari. Item terkait persiapan dibincangkan sejak penyiapan, pencucian wadah, cara penyesuaian suhu air dari wadah bibit ikan ke air yang diisikan ke dalam ember. Diskusidiskusi antar peserta yang lebih sering adalah tentang memberi pakan. Pada awal diskusi dibincangkan tentang jadwal dan jumlah pakan yang diberikan. Pada akhir yang ada terkait takaran pakan yang diberikan pada satu kali pemberian. Penyakit atau kelainan pada ikan yang terjadi seperti dari keluhan bakteri, keadaan air yang kemudian berubah menjadi bau, waktu dan teknik penggantian air yang mungkin memberi akibat pada kelainan fisik pada 
ikan. Hilang atau mati terjadi akibat media yang tidak ditutup atau air tumpah akibat hujan. Item Lain ini tentang muncul ide dari mereka untuk mengembangkan wadah dari ember kepada terpal.

Dari kegiatan diskusi antar peserta dalam kelompok dan bagaimana mereka mengembangkan pengetahuan dan pengalaman dalam menghadapi masalah, di antara mereka ada yang muncul sebagai Guru. Pengetahuannya berkembang karena termotivasi untuk berselancar mencari informasi-informasi yang bermanfaat di internet, mencobanya, kemudian berbagi hasil yang diperoleh kepada rekan-rekan dalam kelompok.

Ketertarikan, menemukan kegiatan yang menyenangkan, dan tumbuh harapan-harapan dari kegiatan yang baru menunjukkan ada pertanda positif dari kegiatan baru ini dalam mengurangi tingkat stress yang pernah diterima oleh sebagian dari para peserta karena dihentikan untuk sementara dari kegiatan rutin mereka sebagai buruh lepas harian. Dari sebagian mereka ada yang mengembangkan kepada beternak di kolam berbentuk persegi yang dibuat dari terpal.

\section{Simpulan}

Stress adalah gejala normal pada tubuh dalam merespon keterancaman yang dialami oleh fisik dan psikis dengan mode "lawan-atau-lari" dengan disertai produksi adrenalin dan kortisol yang berfungsi untuk memenuhi keadaan-keadaan fisik yang diperlukan. Stress tidak boleh dibiarkan terjadi secara terus menerus, karena akan menghasilkan adrenalin dan kortisol yang berlebih, sehingga mengganggu sistem kekebalan tubuh. Ketika kekebalan terganggu, tubuh menjadi kurang sensitif dalam merespon stres, menjadi kurang atau tidak kebal terhadap keluhan fisik yang terjadi, maka masalah gangguan kesehatan muncul akibat stress yang tidak wajar.

Teknik pengelolaan stres adalah metoda untuk mengelola stres agar berlangsung dalam setting yang wajar. Sehingga kemunculan stress menjadi positif bagi perkembangan sel-sel dalam jumlah yang cukup bagi merawat kesehatan dan kebugaran. Teknik pengelolaan stress berhasil atau tidak ditentukan oleh pengetahuan dan keterampilan orang yang mengalami stress itu sendiri. Di samping itu, setiap orang memerlukan teman yang peduli membantu bagaimana dia melalui masa-masa stress dengan cukup baik. Yakni fasilitator pengelolaan stress. Setiap kita akan terkena stress, karena itu setiap kita memerlukan kehadiran seorang fasilitator pengelolaan stress.

Kegiatan beternak ikan dalam media terbatas seperti ember dapat langsung dicoba oleh pihak dengan kemampuan ekonomi lemah, seperti pekerja harian lepas di atas. Budidaya ikan di media terbatas diharapkan tidak hanya dapat menjadi media hiburan di waktu luang, baik bagi individu, dalam keluarga, maupun dalam komunitas dengan kegiatan yang serupa, melainkan juga dapat dikembangkan menjadi bentuk kegiatan yang bermanfaat selanjutnya, baik dalam pengembangan keterampilan individu dalam beternak maupun pengembangan untuk tujuan ekonomi.

\section{Ucapan Terima Kasih}

Kegiatan ini didanai dari Hibah Pengabdian Pembinaan Fakultas Teknik Universitas Bengkulu Tahun 2020. Kegiatan workshop diselenggarakan di Sanggar Seni dan Budaya Desa Panca Mukti Kecamatan Pondok Kelapa Kabupaten Bengkulu Tengah. Mahasiswa yang terlibat adalah Zafira Ulfa dan Rasyid Ridho. 


\section{Daftar Pustaka}

Agnvall, E. (2014). Stress! Don't Let It Make You Sick. New research reveals the links between stress and disease. AARP Bulletin. Diunduh dari https://www.aarp.org/health/healthy-living/info-2014/stress-and-disease.html tanggal 10 Oktober 2020.

Alwasiti, H., bin Aris, I., \& Jantan, A. (2010). EEG activity in muslim prayer: A pilot study. Maejo International Journal of Science and Technology, 4(3), 496 - 511. Diunduh dari: http://www.mijst.mju.ac.th/vol4/496-511.pdf tanggal 20 Oktober 2020.

Andrade, C., and Radhakrishnan, R. (2009). Prayer and healing: A medical and scientific perspective on randomized controlled trials. Indian Journal of Psychiatry, 51(40), 247 253. Diunduh dari: https://pubmed.ncbi.nlm.nih.gov/19742190/ tanggal 20 Oktober 2020.

Astuti, S. A. D. (2021). Dampak Covid-19 terhadap ketenagakerjaan dan UMKM di Mojokerto, Jurnal Inovasi Penelitian, v1(9), h 1775.

Batubara, J.P., Rumondang, dan Laila, K. (2021). Penyuluhan peningkatan ketahanan pangan masa Pandemi Covid-19 melalui usaha budidaya ikan di pekarangan di Desa Bangun Sari Kecamatan Silau Laut Kabupaten Asahan. Rambate, J Pengabdian Kepada Masyarakat, v1(1), h. 27.

Doufesh, H., Ibrahim, F., \& Wan Ahmad, W. A. (2014). Effect of Muslim Prayer (Salat) on a Electroencephalography and its Relationship with Autonomic Nervous System Activity. Journal of Alternative and Complementary Medicine, 20(7), 558 - 562. Diunduh dari: https://www.ncbi.nlm.nih.gov/pmc/articles/PMC4086364/ tanggal 20 Oktober 2020.

Duckro, P. N., \& Magaletta, P. R. (1994). The effect of prayer on physical health; Experimental evidence. Journal of Religion and Health, 33(3), 211 - 219. Diunduh dari: https://pubmed.ncbi.nlm.nih.gov/24264027/ tanggal 20 Oktober 2020.

Maitlis, Sally. (2020). Making Sense of the Future After Losing a Job You Love. Harvard Business Review. Diunduh dari: https://hbr.org/2020/04/making-sense-of-the-future-afterlosing-a-job-you-love tanggal 10 Oktober 2020.

Masters, K. S., \& Spielmans, G. I. (2007). Prayer and health: Review, meta-analysis, and research agenda. Journal of Behavior and Medicine, 30(1), 329 - 338. Diunduh dari: https://link.springer.com/article/10.1007/s10865-007-9120-9 tanggal: 20 Oktober 2020.

Nursandi, Juli. (2018). Budidaya ikan dalam ember "Budikdamber" dengan aquaponik di lahan sempit. Prosiding Seminar Nasional. Seminar Nasional Pengembangan Teknologi Pertanian VII. Politeknik Negeri Lampung. Diunduh dari: https://jurnal.polinela.ac.id/ index.php/PROSIDING/article/view/1150 tanggal 10 Oktober 2020.

Nursandi, J. (No Date). Budidaya Ikan dalam Ember (BUDIKDAMBER). Diunduh dari: https:// bulelengkab.go.id/assets/instansikab/80/bankdata/prosedur-budidaya-ikan-dalamember-36.pdf tanggal 10 Oktober 2020.

Schlitz, M. (2005). Meditation, prayer and spiritual healing: The evidence. The Permanente Journal, 9(3), $63-66$.

Scot, Elizabet. (2020). The Main Causes of Stress. What impacts you most may not be the same as for someone else. Stress Management. Diunduh dari https://www.verywellmind.com/what-are-the-main-causes-of-stress-3145063 tanggal 10 Oktober 2020.

Smith, M.; Segal, J.; Robinson, L.. (2020) Job Loss and Unemployment Stress. Stress Management. Diunduh dari: https://www.helpguide.org/articles/stress/job-loss-andunemployment-stress.htm) tanggal 10 Oktober 2020. 
Stress (2021). Mental health topics: A-Z. Mental Health Foundation. Diunduh dari: https://www.mentalhealth.org.uk/a-to-z/s/stress tanggal 15 Oktober 2020.

Stress Management. (2021) Stress Management Health Center. WebMD Blogs. Diunduh dari https://www.webmd.com/balance/stress-management/stress-management tanggal: 10 Oktober 2020.

Stress Symptoms. (2021). Stress Management. Diunduh dari: https://www.webmd.com/balance/stress-management/ tanggal 15 Oktober 2020.

The Top 5 Most Stressful Life Events and How to Handle Them. (2015). University Hospitals Blog. Diunduh dari: https://www.uhhospitals.org/Healthy-at-UH/articles/2015/07/the-top5-most-stressful-life-events tanggal 10 Oktober 2020.

What Is Stress-Related Illness? (2018). Healthline. Diunduh dari: https://www.healthline.com/health/what-is-stress-related-illness\#prolonged-stress tanggal 10 Oktober 2020. 